\title{
LUMBRICIDAE IN THE PROCESS OF MONITORING OF THE STATE OF LAND RECLAMATION OF FORMER SULPHUR MINE IN JEZIÓRKO
}

\author{
Anna Mazur-Pączka', Grzegorz Pączka', Joanna Kostecka' \\ 1 Department of Natural Theories of Agriculture and Environmental Education, Faculty of Biology and \\ Agriculture, University of Rzeszów, M. Ćwiklińskiej 1A, 25-601 Rzeszów, e-mail: jkosteck@ur.edu.pl
}

Received: 2017.08.15

Accepted: 2017.10.01

Published: 2017.11.01

\begin{abstract}
The aim of the research was to evaluate the advancement of the naturalisation process that concerned the reclaimed area of the former the sulphur mine in Jeziorko. It was assessed by analising the diversity of earthworms populations from the chosen five spots (field I, II, X, XX and XXI) differentiated in terms of time and direction of reclamation. Earthworms were obtained by the mixed method, according to Zajonc. The results were analyzed statistically. On the field II reclaimed for the longest period in forest direction, all 7 species of Lumbricidae were found, whereas on field X (shorter reclamation) -5 of them. In the open spaces of fields I, XX and XXI, representatives of the examined group were not present. On field XX and XXI, earthworms were preserved only within individual old trees (Malus Mill., Populus L. poplar) growing in this area even before the period of land degradation by the sulphur mines. Within the crowns of these trees, poor clusters consisting of 1 or 2 species of earthworms were discovered (A. rosea and/or A. caliginosa).
\end{abstract}

Keywords: Lumbricidae, sulfur mine, reclamation, residues of natural biocenoses

\section{INTRODUCTION}

As a result of the rapid development of civilization, the soil was burdened by a number of harmful factors [Siuta 2009, Skiba and Poskrobko 2010, Kaniuczak et al. 2013, Kucharski and Kalitowska 2015]. This is of great importance, as the soil performs a number of functions that are essential in environmental, economic and social terms. Soil is alive - it constantly undergoes the processes of synthesis and decomposition of mineral and organic compounds, which is the basis of the circulation of matter and energy flow [Skiba and Poskrobko 2010]. Currently, it is estimated that one quarter of all organisms living on Earth lives in the soil and thus it is sometimes called "the roof of the world" or "factory of life on earth" [Commission of the Communities ... 2002]. Biodiversity of the organisms living in it constitutes the basis for the correct functioning of the soil and the basis of life on our planet.

Among the macrofauna of the soil, an important component includes earthworms (Lumbric- idae). They are the predominant part of zooedafon biomass, that is, organisms living in the subsurface soil [Blouin et al. 2013]. Earthworms are involved in the formation of soil structure and nutrient cycling and are a source of valuable protein for many animal species. Due to the key functions of the soil, these organisms are used in monitoring the state of the environment.

The purpose of the paper was to present the possibility of assessing the status of degraded lands reclamation with earthworms participation and to draw the attention to the role of residuals of natural phyto- and zoocenoses in restoration of the full composition of biodiversity of these areas.

\section{RESEARCH AREA AND METHODS}

The research was conducted within the areas of former Siarka Machów S.A. mine in the area of Jeziórko (Podkarpackie voivodship, Grębów commune) on 5 sites differentiated in terms of time and 
direction of reclamation (Table 1) [Przedsiębiorstwo Rekultywacji ... 2001].

On the research sites, earthworms were obtained by the mixed method according to Zajonc [1970] and proposed by ISO [EN ISO 23611-1: 2006]. Earthworms were searched by hand, sorting the soil blocks with the dimensions of $25 \times 25 \times 25 \mathrm{~cm}$. Earthworms from the deeper layers of the profile were extracted by gradually flooding of the surface of a hole resulting from the sample selection with 10 liters of $0.4 \%$ formalin solution.

Samples were collected in annual cycles on a monthly basis, from May to November and from April to November next year. The individuals were identified and weighed within a few days (RADWAG laboratory scale WAX 160/X). Identification of species was performed in the laboratory of the Department of Natural Theories of Agriculture and Environmental Education of University of Rzeszów using a binocular magnifier (OPTA-TECH model SZMCTV1/2) and keys for species identification for land earthworms of Poland [Plisko 1973, Kasprzak 1986].

Soil from each site was collected for analysis of its granulometric composition by the Bouyoucos' areometric method and modified by Casagrande and Prószyński in accordance with PN-R-04032:1998 standard. Using a potentiometric method, a $\mathrm{pH}$ of $1 \mathrm{~mol} \cdot \mathrm{dm}^{-3} \mathrm{KCl}$ was marked.
The humus content was determined by the Tiurin method, content of assimilable forms of phosphorus and potassium (by Egner-Riehm method) and magnesium (by Schachtschabel method) [Mocek et al. 2000, Karczewska and Kabała 2008].

\section{Statistical analysis}

The obtained data were presented as mean \pm standard deviation (SD). The results were analyzed statistically in STATISTICA v. 10 software. Comparing the two groups, the t-student test was used. If the assumptions for the parametric test were not met, its non-parametric equivalent was used (U Mann-Whitney's test).

\section{RESULTS AND DISCUSSION}

In a less environmentally friendly environment -within the reclaimed areas of the former Siarka Machów S.A. mine in Jeziórko, a total of 7 species of earthworms were found. On the field II reclaimed for the longest period, there were all 7 species found, and on field $X-5$ of them (Table 2). In the open spaces of fields I, $\mathrm{XX}$ and XXI, representatives of the examined group were not found. On field XX and XXI, earthworms were preserved only within individual old trees (Malus Mill., Populus L. pop-

Table 1. Lumbricidae collection sites in the reclaimed areas of former Siarka Machów S.A. mine in the area of Jeziórko

\begin{tabular}{|c|c|c|}
\hline Site & Reclamation & Soil conditions \\
\hline $\begin{array}{c}\mathrm{I} \\
\text { N } 50^{\circ} 34^{\prime} 10.6^{\prime \prime} \\
\text { E } 021^{\circ} 46^{\prime} 03.7^{\prime \prime}\end{array}$ & $\begin{array}{l}\text { Conducted in the years 1989-1992 in meadow direction, } \\
\text { flotation lime, sewage sludge, mineral and organic fertilizers } \\
\text { were applied and alfalfa was planted (Medicago L.) with a } \\
\text { grass mixture: meadow fescue (Festuca pratensis Huds.), } \\
\text { lolium multiflorum (Lolium multiflorum Lam.), common } \\
\text { hornbill (Dactylis glomerata L.) and timothy grass (Phleum } \\
\text { pratense L.) }\end{array}$ & $\begin{array}{l}\text { Sandy clay; } \\
\text { pH w KCl 5.8; humus } 0.48 \% ; 5.0 \text { mg } \\
\mathrm{P}_{2} \mathrm{O}_{5} / 100 \mathrm{~g} \text { s.m.; } 7.2 \text { mg K } \mathrm{O} / 100 \mathrm{~g} \mathrm{s.m.;} \\
4.9 \mathrm{mg} \mathrm{Mg} / 100 \mathrm{~g} \text { s.m. }\end{array}$ \\
\hline $\begin{array}{c}\text { II } \\
\text { N } 50^{\circ} 34^{\prime} 12.3^{\prime \prime} \\
\text { E } 021^{\circ} 46^{\prime} 04.3^{\prime \prime}\end{array}$ & $\begin{array}{l}\text { Consisting of several stages, completed in 1992, } \\
\text { removed sulfur contamination in solid form, introduced } \\
\text { soil, introduced lime flotation, added sludge and mineral } \\
\text { fertilizers, red oak (Quercus rubra L.), birch (Betula L.) and } \\
\text { pine (Pinus L.) were planted }\end{array}$ & $\begin{array}{l}\text { Sandy clay; } \\
\text { pH w KCl } 6.7 ; \text { humus } 0.58 \% ; 19.1 \text { mg } \\
\mathrm{P}_{2} \mathrm{O}_{5} / 100 \mathrm{~g} \text { s.m.; } 2.8 \text { mg K } \mathrm{K}_{2} \mathrm{O} / 100 \mathrm{~g} \mathrm{s.m.;} \\
6.8 \mathrm{mg} \mathrm{Mg} / 100 \mathrm{~g} \text { s.m. }\end{array}$ \\
\hline $\begin{array}{c}\mathrm{X} \\
\mathrm{N} 50^{\circ} 34^{\prime} 16.8^{\prime \prime} \\
\mathrm{E} 021^{\circ} 47^{\prime} 59.7^{\prime \prime}\end{array}$ & $\begin{array}{l}\text { Conducted in the years 1995-1997 in forest direction, } \\
\text { application of large quantities of earth masses, the use of } \\
\text { lime flotation and mineral fertilizers, the planting of birch } \\
\text { (Betula L.) and pine (Pinus L.) }\end{array}$ & $\begin{array}{l}\text { Clay sand; } \\
\mathrm{pH} \text { w } \mathrm{KCl} 6.6 \text {; humus } 0.26 \% ; 19.5 \mathrm{mg} \\
\mathrm{P}_{2} \mathrm{O}_{5} / 100 \mathrm{~g} \mathrm{s.m.;} 10.1 \mathrm{mg} \mathrm{K} \mathrm{O}_{2} / 100 \mathrm{~g} \\
\text { s.m.; } 4.5 \mathrm{mg} \mathrm{Mg} / 100 \mathrm{~g} \mathrm{s.m.}\end{array}$ \\
\hline $\begin{array}{c}\mathrm{XX} \\
\mathrm{N} 50^{\circ} 31^{\prime} 16.1^{\prime \prime} \\
\mathrm{E} 021^{\circ} 50^{\prime} 00.1^{\prime \prime}\end{array}$ & \multirow{2}{*}{$\begin{array}{l}\text { Site located in a strongly degraded area, with the most } \\
\text { recently started reclamation (in 2012) in meadow direction, } \\
\text { there are water reservoirs formed by the settlement of } \\
\text { land, the descent of groundwater and the accumulation } \\
\text { of precipitation waters. From earlier periods, in the open } \\
\text { landscape, single trees were preserved here - wild apples } \\
\text { (malus mill.) and poplars (populus I.) }\end{array}$} & $\begin{array}{l}\text { Clay sand; } \\
\mathrm{pH} \text { w KCl } 6.5 ; \text { humus } 0.34 \% ; 12.4 \text { mg } \\
\mathrm{P}_{2} \mathrm{O}_{5} / 100 \mathrm{~g} \mathrm{s.m.;} 6.3 \text { mg K} \mathrm{O} / 100 \mathrm{~g} \text { s.m.; } \\
4.4 \mathrm{mg} \mathrm{Mg} / 100 \mathrm{~g} \mathrm{s.m.}\end{array}$ \\
\hline $\begin{array}{c}\text { XXI } \\
\text { N } 50^{\circ} 31^{\prime} 20.2^{\prime \prime} \\
\text { E 021 } 51^{\circ} 50^{\prime} 12.9^{\prime \prime}\end{array}$ & & $\begin{array}{l}\text { Clay sand; } \\
\text { pH w KCl } 3.9 \text {; humus } 0.19 \% ; 1.5 \text { mg } \\
\mathrm{P}_{2} \mathrm{O}_{5} / 100 \mathrm{~g} \text { s.m.; } 1.7 \text { mg K} \mathrm{K}_{2} \mathrm{O} / 100 \mathrm{~g} \mathrm{s.m} \text {; } \\
3.3 \mathrm{mg} \mathrm{Mg} / 100 \mathrm{~g} \text { s.m. }\end{array}$ \\
\hline
\end{tabular}


Table 2. The species structure and earthworms' classification to morpho-ecological groups in the sites in Jeziórko

\begin{tabular}{|c|c|c|c|c|c|}
\hline \multirow{2}{*}{ Morpho-ecological group/species } & \multicolumn{5}{|c|}{ Field } \\
\hline & 1 & II & $\mathrm{X}$ & $\mathrm{XX}$ & XXI \\
\hline \multicolumn{6}{|c|}{ Epigees } \\
\hline D. rubidus tenuis & - & + & + & - & - \\
\hline D. octaedra & - & + & + & - & - \\
\hline \multicolumn{6}{|c|}{ intermediate group } \\
\hline L. rubellus & - & + & - & - & - \\
\hline \multicolumn{6}{|c|}{ Endogees } \\
\hline A. caliginosa & - & + & + & - & - \\
\hline A. rosea & - & + & + & - & - \\
\hline O. lacteum & - & + & + & - & - \\
\hline \multicolumn{6}{|c|}{ Aneciques } \\
\hline L. terrestris & - & + & - & - & - \\
\hline
\end{tabular}

* according to Bouché [1977];

lar) growing in this area even before the period of land degradation by the sulfur mines. Within the crowns of these trees, poor clusters consisting of 1 or 2 species of earthworms were found (A. rosea and/or A. caliginosa).

On field II which was reclaimed first, there were representatives of three morpho-ecological groups found. There was one representative of the group of Epigees earthworms - D. rubidus and one representative of intermediate group - L. rubellus. Earthworms from Endogees, digging horizontal corridors were represented by 3 species: $A$. caliginosa, A. rosea and O. lacteum. There was also one representative of deep-digging Aneciques earthworms - L. terrestris (tab. 2). On field $\mathrm{X}$ (reclaimed later), surface species were found$D$. rubidus and D. octaedra and earthworms digging shallow horizontal corridors: A. caliginosa, $A$. rosea and O. lacteum (tab. 2).

The number of earthworm species in each dominance classes on the reclaimed fields is shown in figure 1 .

The mean density of the earthworm population found was $80 \pm 24$ individuals per $\mathrm{m}^{2}$. The employed tests did not show statistical differences for Lumbricidae density in field II

a)

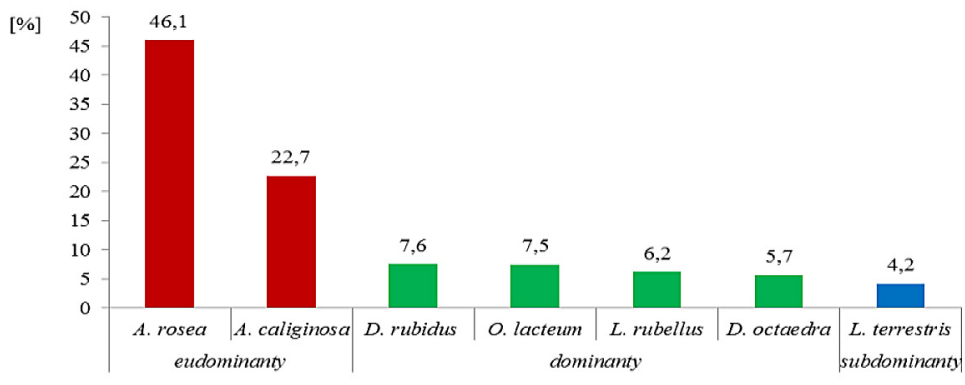

c)

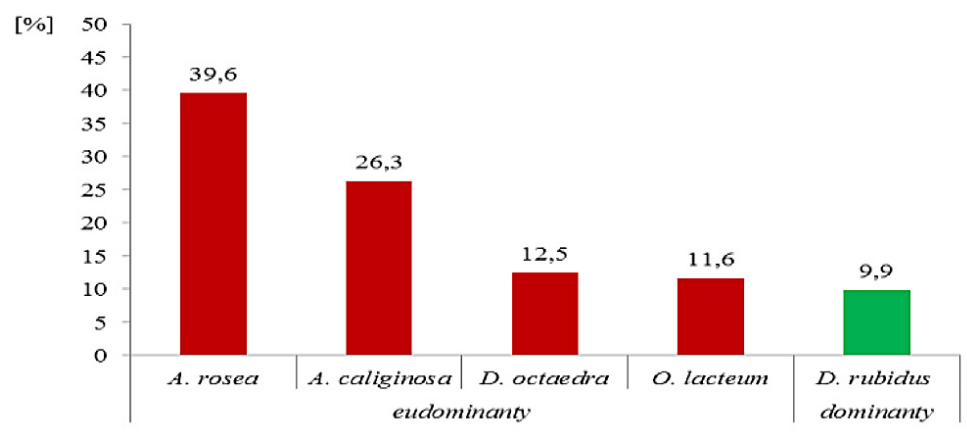

Fig. 1. Dominance [\%] of species found in Jeziórko: a) on field II and b) on field X 
Table 3. Number of earthworms in reclaimed areas in Jeziórko [ind. $\cdot \mathrm{m}^{-2}$ ]

\begin{tabular}{|c|l|c|c|c|}
\hline \multirow{2}{*}{ Year } & \multicolumn{2}{|c|}{ Sites in Jeziórko } & average \\
\cline { 2 - 5 } & May & field II & $54 \pm 7$ & $46 \pm 11$ \\
\hline \multirow{5}{*}{2012} & $38 \pm 7$ & $40 \pm 5$ & $47 \pm 10$ \\
\cline { 2 - 4 } & June & $54 \pm 8$ & $42 \pm 5$ & $48 \pm 9$ \\
\cline { 2 - 4 } & July & $54 \pm 8$ & $20 \pm 5$ & $32 \pm 17$ \\
\cline { 2 - 5 } & August & $44 \pm 8$ & $44 \pm 9$ & $60 \pm 23$ \\
\cline { 2 - 5 } & September & $76 \pm 14$ & $60 \pm 17$ & $99 \pm 55$ \\
\cline { 2 - 5 } & October & $138 \pm 28$ & $122 \pm 42$ & $128 \pm 8$ \\
\cline { 2 - 5 } & November & $134 \pm 22$ & $52 \pm 7$ & $129 \pm 16$ \\
\hline \multirow{5}{*}{2013} & April & $50 \pm 8$ & $118 \pm 30$ & $100 \pm 51$ \\
\cline { 2 - 5 } & May & $140 \pm 35$ & $64 \pm 8$ & $97 \pm 58$ \\
\cline { 2 - 5 } & June & $136 \pm 23$ & $56 \pm 9$ & $96 \pm 8$ \\
\cline { 2 - 5 } & July & $138 \pm 25$ & $48 \pm 6$ & $117 \pm 21$ \\
\cline { 2 - 5 } & August & $60 \pm 10$ & $72 \pm 12$ & $93 \pm 33$ \\
\cline { 2 - 5 } & September & $120 \pm 19$ & $102 \pm 9$ & $80 \pm 24$ \\
\cline { 2 - 5 } & October & $132 \pm 20$ & $70 \pm 20$ & \\
\cline { 2 - 5 } & November & $116 \pm 21$ & $65 \pm 13^{\text {a }}$ & \\
\hline
\end{tabular}

and field $\mathrm{X}$, which was reclaimed slightly later (tab. 3) $(\mathrm{p}>0.05)$.

The biomass of earthworms amounted to the average of $36.29 \pm 12.81 \mathrm{~g} \cdot \mathrm{m}^{-2}$ and similarly there were no statistically significant differences for average biomass on fields II and X (tab. 4) ( $p>0.05$ ).

The areas of the former sulfur mine in Jeziórko, although reclaimed, are still unfavorable to zooedafon. This is mainly due to the insufficient content of organic matter in the ground and the locally poorly planted cover (Table 1 ). In particular, field I (reclaimed in the years 1989-1992 in the meadow direction with currently still un- spoilt grassland) and fields XX and XXI (with reclamation started in 2012) were particularly disadvantageous. No earthworms were found on these sites. Fields XX and XXI were small areas under the crowns of single trees: apple and poplar, where fragments of old clusters were preserved, in the form of one or two species of earthworms. Similar small "islands" with populations of these invertebrates have been identified by Tosza et al. [2010] in the area near Olkusz. Heterogeneity of habitats in the reclaimed areas may result in locally more favorable conditions for the occurrence of different species. The root zones of

Table 4. Biomass of earthworms in the soil of reclaimed sites within Jeziórko $\left[\mathrm{g} \cdot \mathrm{m}^{-2}\right]$

\begin{tabular}{|c|c|c|c|c|}
\hline \multirow{2}{*}{ Year } & \multirow{2}{*}{ Month } & \multicolumn{3}{|c|}{ Sites in Jeziórko } \\
\hline & & field II & field $X$ & average \pm SD \\
\hline \multirow{7}{*}{2012} & May & $11.12 \pm 3.21$ & $13.17 \pm 2.25$ & $12.15 \pm 1.45$ \\
\hline & June & $16.24 \pm 2.53$ & $8.67 \pm 1.67$ & $12.46 \pm 5.35$ \\
\hline & July & $15.91 \pm 2.58$ & $12.07 \pm 2.09$ & $13.99 \pm 2.71$ \\
\hline & August & $13.60 \pm 2.60$ & $7.74 \pm 2.14$ & $10.67 \pm 4.14$ \\
\hline & September & $37.29 \pm 7.20$ & $21.19 \pm 4.52$ & $29.24 \pm 11.38$ \\
\hline & October & $51.13 \pm 10.33$ & $30.23 \pm 9.95$ & $40.68 \pm 14.78$ \\
\hline & November & $65.26 \pm 11.04$ & $53.78 \pm 20.92$ & $59.52 \pm 8.12$ \\
\hline \multirow{8}{*}{2013} & April & $16.08 \pm 3.11$ & $14.69 \pm 2.76$ & $15.39 \pm 0.98$ \\
\hline & May & $44.27 \pm 11.72$ & $57.52 \pm 16.74$ & $50.90 \pm 9.37$ \\
\hline & June & $37.84 \pm 6.05$ & $25.26 \pm 3.97$ & $31.55 \pm 8.90$ \\
\hline & July & $70.26 \pm 13.74$ & $22.66 \pm 4.66$ & $46.46 \pm 33.66$ \\
\hline & August & $47.55 \pm 9.57$ & $20.52 \pm 3.26$ & $34.04 \pm 19.11$ \\
\hline & September & $77.24 \pm 12.32$ & $31.55 \pm 6.39$ & $54.40 \pm 32.30$ \\
\hline & October & $36.38 \pm 6.39$ & $26.55 \pm 2.55$ & $31.47 \pm 6.95$ \\
\hline & November & $33.20 \pm 4.62$ & $19.10 \pm 4.99$ & $26.15 \pm 9.97$ \\
\hline \multicolumn{2}{|r|}{ Average \pm SD } & $38.23 \pm 7.13^{a}$ & $24.3 \pm 5.92^{a}$ & $36.29 \pm 12.81$ \\
\hline
\end{tabular}


old, preserved island trees offer both greater organic matter and relative humidity of the habitat. In light of the above, saving even small residues of complex habitat should be given priority and when planning the reclamation process, during degradation activities, one should not allow for their complete destruction.

The number and biomass of earthworms lie on the background of the soil profile according to morpho-ecological groups. The filling of morphoecological groups of earthworms in a given area may change. According to the Eijsackers [2011], in the early stages of reclamation, there are mainly species from the epigees and endogees groups, and aneciques become present only with time. According to the same author, on the reclaimed post-mining areas, the from the epigees group, which are characterized by quick growth and high fertility index constitute the first colonists. They live above the mineral part of the soil in the litter and they are therefore not directly exposed to the impact of mineral deposits located below.

The spreading rate of earthworms on the reclaimed areas is different. It may be very fast (91-133 $\mathrm{m}$ in 6 years) and much slower (10-20 m over 10-15 years) [Ligthart and Peek 1997, Eijsackers 2011]. The ability to occupy new ecological niches by earthworms is dictated by their natural rate of dispersion. It also seems that transport with the masses of the earth, transporting them along with the vegetation, and through animals and machines play an important role in the propagation of earthworms in reclaimed areas [Holdsworth et al. 2007].

In Jeziórko, the only species from the deepdigging group (L. terrestris) was found only on field II (tab. 5). It was not found on this site in studies previously conducted by Kostecka et al. [2004], which probably resulted from too short time of reclamation and the habitat conditions which were not favorable enough for this species. The appearance of $L$. terrestris on this site 10 years later may indicate the advancement of reclamation process. As provided by Mather and Christensen [1992], L. terrestris can move on the surface of the soil. During a single night it can move up to $19 \mathrm{~m}$, which would explain its spread in the Jeziórko from neighboring old forest areas. L. terrestris could also have been accidentally stuck to this site during reclamation works. Research may indicate that on X field reclaimed for a shorter period, it is still too early for successful succession of this species. The reason is probably a poorly developed soil profile, the depth of which is determined by the presence of earthworms from the deep digging group [Eijsackers 2011].

On fields II and X, the density of earthworms was noted as $96 \pm 17$ and $65 \pm 13$ individuals per $\mathrm{m}^{2}$, respectively (tab. 3 ). These were high values with reference to the data obtained on the same sites ten years earlier by Kostecka et al. [2004] $\left(15.5 \pm 14.7\right.$ ind. $\cdot \mathrm{m}^{-2}$ and $1.4 \pm 1.4$ ind. $\left.\cdot \mathrm{m}^{-2}\right)$. Such a considerable difference may be the effect of the passing time and the ongoing reclamation processes as well as the development rate of earthworms population. The density of Lumbricidae found in Jeziórko is also higher in comparison with data obtained by Łapiński and Rościszewska [2003] in the area of the Boleslaw ironworks (7 ind. $\mathrm{m}^{2}$ ). Lower earthworms density values were also reported by Van Gestel et al. [2009] in the areas contaminated with zinc and cadmium (17-86 ind. - $\mathrm{m}^{2}$ ). However, studies of the afore-mentioned authors were conducted in the areas contaminated with heavy metals, which usually prevents the development of numerous earthworm populations.

On field II of areas reclaimed in Jeziórko, the biomass of earthworms amounted to $38.23 \pm 7.13$ $\mathrm{g} \cdot \mathrm{m}^{-2}$ and on field $\mathrm{X}$ to $-24.31 \pm 5.92 \mathrm{~g} \cdot \mathrm{m}^{-2}$ (tab. 4). These values were higher than the data from $2004\left(5.7 \pm 4.6\right.$ and $0.36 \pm 0.38 \mathrm{~g} \cdot \mathrm{m}^{-2}$, respectively) [Kostecka et al. 2004]. The currently indicated biomass growth is most likely due to the reclamation and development of earthworm populations. On field II, the size of biomass of earthworms was influenced by the presence of a large species $L$. terrestris (tab. 2), which was not found on this site earlier [Kostecka et al. 2004].

\section{CONCLUSIONS}

1. The monitoring of the state of land reclamation in Jeziórko, conducted with the presence of Lumbricidae, indicates their unevenness.

2. Research has shown the great role of residuals of natural phyto- and zoocenoses in restoring the biodiversity composition of the reclaimed land. This necessitates the preservation and protection of as large and varied groups of trees and shrubs as possible in the areas threatened by degradation. They constitute a stable habitat for biodiversity, including earthworms which are able to migrate from it and successively recreate ecosystems, thus accelerating reclamation. 


\section{REFERENCES}

1. Blouin M., Hodson M.E., Delgado E.A., Baker G., Brussaard E., Butt K.R., Dai J., Dendooven L., Peres G., Tondoh J.E., Cluzeau D., Brun J.J. 2013. A review of earthworm impact on soil function and ecosystem services. European Journal of Soil Science, 64, 161-182.

2. Commission of the European Communities. Communication from the Commission to the Council, the European Parliament, the European Economic and Social Committee and the Committee of the Regions. Thematic strategy for soil protection. 2002. Bruksela.[Dokument elektroniczny: http:// eurlex.europa.eu/LexUriServ/LexUriServ.do?uri =COM:2006:0231:FIN:PL:HTML, data wejścia $02.01 .2014]$

3. Eijsackers H. 2011. Earthworms as colonizers of natural and cultivated soil environments. Applied Soil Ecology, 50, 1-13.

4. EN ISO 23611-1:2006. Soil quality. Sampling of soil invertebrates. Part 1. Hand-sorting and formalin extraction of earthworms. Geneva. Switzerland.

5. Holdsworth A.R., Frelich L.E., Reich P.B. 2007. Regional extent of an ecosystem engineer: earthworm invasion in northern hardwood forests. Ecological Application, 17(6), 1666-1677.

6. Kaniuczak J., Stanek-Tarkowska J., Augustyn Ł., Szostek M., Knap R., Szewczyk A. 2013. Wykorzystanie i ochrona zasobów powierzchni gruntów w województwie podkarpackim. Inżynieria Ekologiczna, 34, 149-157.

7. Karczewska A., Kabała C. 2008. Metodyka analiz laboratoryjnych gleb i roślin. UP Wrocław. [Dokument elektroniczny: http://www.ar.wroc.pl/ kabal, data wejścia: 5.07.2015].

8. Kasprzak K. 1986. Skąposzczety glebowe III. Rodzina Dżdżownice (Lumbricidae). Klucz do oznaczania bezkręgowców Polski. Wydawnictwo Naukowe PWN. Warszawa.

9. Kostecka J., Pączka G., Mastalerczyk A. 2004. Ocena procesu rekultywacji terenów po kopalni siarki w Jeziórku na podstawie stanu fauny dżdżownic. Zeszyty Problemowe Postępów Nauk Rolniczych, 498, 135-145.
10. Kucharski M., Kalitowska O. 2015. Clopyralid dissipation in the soil contaminated with heavy metals. Journal of Ecological Engineering, 16(1), 38-42.

11. Ligthart T.N., Peek G.J.C.W. 1997. Evolution of earthworm burrow system after inoculation of lumbricid earthworm in a pasture in the Netherlands. Soil Biology and Biochemistry, 29, 453-462.

12. Łapiński S., Rościszewska M. 2003. Różnice w kumulacji metali ciężkich u Lumbricus rubellus (Hoff.) i Dendrobaena octaedra (Sav.) Rocznik Nauk Zootechnicznych, Supl., 17,751-754.

13. Mather J.G., Christensen O. 1992. Surface migration of earthworms in grassland. Pedobiologia, 36(1), 51-57.

14. Mocek A., Drzymała S., Maszner P. 2000. Geneza, analiza i klasyfikacja gleb. Akademia Rolnicza w Poznaniu.

15. Plisko D.J. 1973. Lumbricidae dżdżownice (Annelida: Oligochaeta). Fauna Polski 1. Wydawnictow Naukowe PWN. Warszawa.

16. Przedsiębiorstwo Rekultywacji Terenów Górniczych „Jeziórko”. 2001. Koszty rekultywacji poniesione w latach 1997-2001.

17. Siuta J. 2009. Degradacja i rekultywacja powierzchni ziemi w Polsce. Zeszyty Naukowe Poł.-Wsch. Oddziału PTIE i PTG w Rzeszowie, 11, 235-241.

18. Skiba K., Poskrobko T. 2010. Degradacja gleb - problem globalny. [Dokument elektroniczny: http://www.kee.ue.wroc.pl/old/poskrobko/pliki/ degradacja_gleb.pdf, data wejścia 19.09.2013].

19. Tosza E., Dumnicka E., Niklińska M., Rożen A. 2010. Enchytraeid and earthworms communities along a pollution gradient near Olkusz (southern Poland). European Journal of Soil Biology, 46, 218-224.

20. Van Gestel C.A.M., Koolhaas J.E., Hamers T., Van Hoppe M., Van Roovert M., Korsman C., Reinecke S.A. 2009. Effects of metal pollution on earthworm communities in a contaminated floodplain area: Linking biomarker, community and functional responses. Environmental Pollution, 157, 895-903.

21. Zajonc I. 1970. Synuzie dazdoviek (Lumbricidae) na lukach karpatskiej oblasti. Ceskoslovenska. Biol. Prace, 16, 1098. 